\title{
Erratum to: Innate lymphoid cells in asthma phenotypes
}

Leyla Pur Ozyigit ${ }^{1 *}$, Hideaki Morita ${ }^{2,3}$ and Mubeccel Akdis 2,3

\section{Erratum to: Clinical and Translational Allergy \\ (2015) 5:23 \\ DOI 10.1186/s13601-015-0068-5}

After publication of the original article, the authors noticed the title was incorrect. The title was published as: "Innate lymphocyte cells in asthma phenotypes"; however, it should be "Innate lymphoid cells in asthma phenotypes", as seen above.

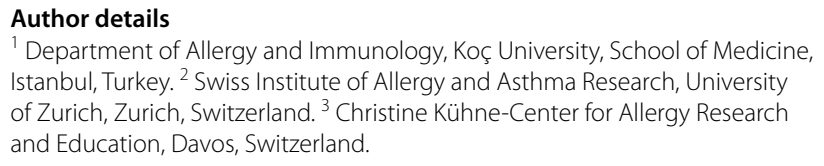

The online version of the original article can be found under doi:10.1186/s13601-015-0068-5.

\footnotetext{
*Correspondence: sozyigit@ku.edu.tr

${ }^{1}$ Department of Allergy and Immunology, Koç University, School of Medicine, Istanbul, Turkey

Full list of author information is available at the end of the article
} 